TITLE:

\title{
Life History Types of the Florideophyceae (Rhodophyta) and their Evolution
}

\author{
AUTHOR(S): \\ Umezaki, Isamu
}

\section{CITATION:}

Umezaki, Isamu. Life History Types of the Florideophyceae (Rhodophyta) and their

Evolution. PUBLICATIONS OF THE SETO MARINE BIOLOGICAL LABORATORY 1989, 34(1-3): $1-24$

ISSUE DATE:

1989-08-31

URL:

http://hdl.handle.net/2433/176162

RIGHT: 


\title{
Life History Types of the Florideophyceae (Rhodophyta) and their Evolution
}

\author{
By \\ Isamu Umezaki ${ }^{1)}$ \\ Laboratory of Fishery Resources, Division of Tropical Agriculture, Graduate School \\ of Agriculture, Kyoto University, Kyoto, 606 Japan
}

With Text-figure 1 and Tables $1-2$

\begin{abstract}
Life histories in the Florideophyceae, Rhodophyta, are classified into eleven types: I (the ancestral type), II (the isomorphic type), III (the heteromorphic type), IV (the Lemanea mamillosa type), V (the Mastocarpus papillatus type), VI (the Liagora tetrasporifera type), VII (the Rhodophysema elegans type), VIII (The Audouinella purpurea type), IX (the Palmaria palmata type), X (the Hildenbrandia prototypas type), and XI (the Audouinella pectinata type). The evolutionary paths from the ancestral type (type I) to type V through type II, type III and type IV (A course), to type VII through type III and type VI (B course), to type X through type III, type VI, type VIII and type IX (C course), and to type XI through type II (D course) in the existing algae are discussed. No close relationship in the life history has been found between phylogenetic orders in the class. The order Nemaliales, the most primitive order, has eight types of life history, being very variable in the evolution of life history, while the orders Rhodymeniales and Ceramiales, which have each two types, are in an evolutionally stable position. Some species in the class have two types of life history: in addition to primitive types (type II and type III) apomictic type (V), non-carposporophyte type (IX) and sporophytic type (type $\mathrm{X}$ ) are known.
\end{abstract}

After Magne (1972), Dixon (1973) and Umezaki (1977) introduced the types of the life histories in the Florideophyceae, Rhodophyta, information on these has increased progressively and also new types of life history were found in Palmaria palmata (van der Meer \& Todd, 1980), Rhodophysema elegans (DeCew \& West, 1982) and Audouinella pectinata (Abdel-Rahman \& Magne, 1983). Dixon (1982), commenting on the Florideophyceae with special reference to the Nemaliales, described five types of life history, 1) Polysiphonia-, 2) Bonnemaisonia-, 3) Lemanea-, 4) Liagora tetrasporifera-, and Palmaria-types, of which the last was newly added to his life history category in 1973. In 1981 West \& Hommersand reviewed recent progress on life history studies in the red algae, subclass Bangiophycidae and subclass Florideophycidae, giving a detailed interpretation on the life histories of some species such as Palmaria palmata, Bonnemaisonia asparagoides, Acrosymphyton purpuriferum and Polysiphonia.

Van der Meer \& Todd (1980) and van der Meer (1981) assumed that the life histories of Palmaria palmata and Devaleraea ramentacea (as Halosaccion ramentacea), respectively, were derived from algae of an ancestral diphasic life history pattern that

1) Present address: Hansei 128-6, Obama, Fukui Pref., 917 Japan.

Publ. Seto Mar. Biol. Lab., 34(1/3), 1-24, $1989 . \quad$ (Article 1) 
existed before the evolution of carposporophyte. Guiry (1987) regarded that the Palmaria palmata type and the Rhodophysema elegans type, both of which have no carposporophyte, are evolutionally more primitive than the Polysiphonia type of life history. On the other hand, Magne (1982) interpreted that the two types are derivatives from the Polysiphonia type, extending his previous proposal in 1972. Moreover, he (Magne, 1987a) considered that the tetrasporophyte of Palmaria palmata is an independent carposporophyte, confirming Feldmann's hypothesis (1952) that the primitive life history in the red algae was composed of three independent generations.

\section{Results and Discussion}

1. Classification of types of life history.

Type I (The Ancestral Type).

Feldmann (1952) proposed a hypothesis that the ancestral life history for the Florideophyceae was composed of a haploid gametophyte, a diploid carposporophyte and a diploid tetrasporophyte, each of which was independent and morphologically identical. This type of life history is morphologically triphasic and karyologically diphasic. Feldmann further considered that the carposporophyte of existing red algae became parasitic in the gametophyte, losing its independence.

Type II (The Isomorphic Type).

The gametophyte and tetrasporophyte of this type are morphologically identical and independent, and the carposporophyte is parasitic on its gametophyte. The life cycle is triphasic and consisted karyologically of a haploid gametophyte, a diploid carposporophyte and a diploid tetrasporophyte. This type is found in all orders of the Florideophyceae except the Palmariales. There are two cases; in some species the gametophyte and tetrasporophyte are similar in size and thallus basal structure and in the other species the two phases are dissimilar, although the difference is slight. The former is included in subtype IIa and the latter in subtype IIb.

Subtype IIa (The Polysiphonia flexicaulis Type).

The gametophyte and tetrasporophyte are similar in size and in superficial habit.

It was karyologically demonstrated that the haploid chromosome number of Leveillea jungermannioides is 23-24 and diploid 46-48 (Rao, 1967).

In Gardneriella tuberifera (Groff, 1981) and Farlowia irregularis (Shimizu \& Masuda, 1983 ) bisporophytes bearing binucleate bispores alternate with morphologically similar gametophytes. They are included in IIa.

Tokida \& Yamamoto (1965) found in Pachymeniopsis yendoi that tetraspores or tetrasporangial contents germinate in the tetrasporophyte to give rise to erect plants producing carpospores and they called this phenomenon "syntagmatic germination." The phenomenon is known in Agardhiella subulata (Osterhaut, 1896, as Rhabdonia tenera), and Anatheca montagne (Bodard, 1966). This is an abnormal life history for three species, because they are usually isomorphic in life history. 
Species showing type IIa are as follows:

Gelidiales: Gelidiaccae-Gelidium coulteri (Macler \& West, 1987).

Cryptonemiales: Halymeniaceae-Grateloupia turuturu (Ohgai \& Matsui, 1976), Halymenia latifolia (Maggs \& Guiry, 1982), Dermocorynus montagnei (Guiry \& Maggs, 1982a). Ghorcocolaceae-Harveyella mirabilis (Goff \& Cole, 1976), Dawesoniocolax bostrychiae (West \& Calumpong, 1988b).

Gigartinales: Gracilariaceae-Gracilaria foliifera (McLachlan \& Edelstein, 1977), G. verrucosa (Yamamoto \& Sasaki, 1987). Gigartinaceae-Rhodoglossum affine) (Chen \& McLachlan, 1979), R. californicum (West \& Guiry in West \& Hommersand, 1981), Gigartina johnstonii (West \& Guiry, 1982), G. acicularis (Guiry \& Cunningham, 1983), Petrocelis hennedyi (Fletcher \& Irvine, 1982), Besa papillaeformis (DeCew \& Silva in West \& Hommersand, 1981). Dumontiaceae-Farlowia irregularis (Shimizu \& Masuda, 1983). Solieriaceae-Gardneriella tuberifera (Goff, 1981).

Rhodymeniales: Champiaceae-Lomentaria hakodatensis (Lee \& West, 1980a), L. baileyana (Yarish et al., 1984), Minium parvum (Moe, 1979), Gastroclonium coulteri (Lee \& West in West \& Hommersand, 1981). Rhodymeniaceae-Binghamiopsis caespitosa (Lee et al. in West \& Hommersand, 1981), Botryocladia pseudodichotoma (Lee \& West in West \& Hommersand, 1981), B. boergesenii (Brodie \& Guiry, 1986), B. ardreana (Brodie \& Guiry, 1988a), B. wynnei (Ballantine, 1988), Cordylecladia erecta (Brodie \& Guiry, 1987, 1988b).

Ceramiales: Rhodomelaceae-Polysiphonia hemisphaerica (Rueness, 1971), $P$. ferulacea (Kapraun, 1977), P. japonica (Kudo \& Masuda, 1986), Murrayella periclados (Aponte \& Ballantine, 1987), Lophocladia lallemandii (Cormaci \& Motta, 1985), Leveillea jungermannioides (Rao, 1967), Symphyocladia pennata (Choi \& Lee, 1987), Rhodomela confervoides (Masuda, 1982), R. lycopodioides f. tenuissima (Masuda, 1982), R. sachaliensis (Masuda, 1982), R. teres (Masuda, 1982), Neorhodomela munita (Masuda, 1982), $N$. aculeata (Masuda, 1982), N. larix (Masuda, 1982), N. oregona (Masuda, 1982). Ceramiaceae-Antithamnion heterocladum (Athanasiadis, 1983), A. plumula var. crispum (=Pterothamnion crispum) (Athanasiadis, 1985), A. nipponicum (Lee \& West, 1980b), A. sparsum (Boo \& Lee, 1983), Callithamnion hookeri (Edwards, 1979; Whittick, 1981), C. baileyii (Whittick \& West, 1979), C. bipinnatum (Rueness \& Rueness, 1980), C. byssoides (Rueness \& Rueness, 1980), C. tetragonum (Rueness \& Rueness, 1985), Antithamnionella sarniensis (Magne, 1986a), Ceramium rubrum (Garbary et al., 1978, 1980), C. strictum (Rueness, 1973), Crouania plenospora (Prince, 1979). Dasyaceae-Dasysiphonia chejuensis (Choi \& Lee, 1988). Delesseriaceae-Grinnelia americana (Yarish et al., 1984), Hypoglossum nipponicum (Notoya, 1986), H. rhizophorum (Ballantine \& Wynne, 1988).

Subtype IIb (The Acrochaetium virgatulum Type).

The gametophyte and tetrasporophyte are dissimilar in size and thallus basal structure, although the difference is slight. The tetrasporophytes are larger than the gametophytes. For example, in Acrochaetium virgatulum the tetrasporophytes are a few millimeters high with a small basal disc, whereas the gametophytes are lower than the tetrasporophytes and their bases are unicellular (Borsje, 1973). 
Nemaliales: Acrochaetiaceae-Acrochaetium dasyae (Stegenga \& Borsje, 1976), A. densum (Stegenga \& Vroman, 1976), A. gynandrum (Abdel-Rahman, 1985a), A. polyblastum (Stegenga \& Borsje, 1977), A. hollandicum (Stegenga \& Borsje, 1977), A. subtillissimum (Abdel-Rahman, 1980), A. unifilum (Abdel-Rahman, 1981), A. virgatulum (Borsje, 1973), A. asparagopsis (Magne, 1977; Abdel-Rahman \& Magne, 1981), Audouinella alariae (Lee \& Kurogi, 1983), A. boryanum (Abdel-Rahman \& Magne, 1984).

Ceramiales: Rhodomelaceae-Symphyocladia latiuscula (Matsuyama \& Masaki, 1975).

Type III (The Heteromorphic Type).

The gametophyte on which carposporophytes are parasitic is foliose and much larger in size than the tetrasporophyte which is branched-filamentous or crustaceous in habit, sometimes microscopic. This heteromorphic type of life history is called "the Bonnemaisonia type" (Dixon, 1973) or "the Halarachnion-type" (DeCew, 1983). This type, however, is divided into three subtypes, according to the morphology of tetrasporophyte.

Subtype IIIa (The Bonnemaisonia hamifera Type).

Carpospores upon germination give rise to irregularly branched filaments that upon maturity form tetraspores. The macroscopic gametophyte alternates with the smaller, branched filamentous tetrasporophyte.

In Nemalion helminthoides the chromosome number of the gametophyte is 10 , haploid and that of the tetrasporophyte 20, diploid (Chen et al., 1978). Magne's counting of chromosomes in the same species was 8 in the gametophyte, assuming that meiosis occurs during tetrasporogenesis (Magne, 1961).

Kornmann \& Sahling (1980) discovered Conchocelis-like shell-boring microthalli of Helminthocladia clavadosii and Scinaia furcellata from Helgoland, Germany. Some isolates of the microthalli produced gametophytes, showing the direct type, and the other reproduced by tetraspores or monospores. Masuda \& Horiuchi (1988) found in winter months acrochaetioid filaments on barnacles on which gametophytes of Nemalion vermiculare grew in the previous summer. In laboratory culture the filaments formed tetrasporangia and the tetraspores from the sporangium germinated into upright gametophytes. The tetraspores of Acrochaetium polyides endophytic in Polyides rotundus developed in culture in fertile gametophytes corresponding to Helminthora divaricata (Magne \& Abdel-Rahman, 1983). The formation of tetrasporangia of the species was stimulated in lower temperatures $\left(10-14^{\circ} \mathrm{C}\right)$ and in short-day condition, while the upright shoots from tetraspore germlings were responsive to higher temperatures $\left(14-18^{\circ} \mathrm{C}\right.$ ) and to long-day condition (Magne \& Abdel-Rahman, 1983; Cunningham \& Guiry, 1985).

Nemaliales: Helminthocladiaceae-Nemalion helminthoides (Chen et al., 1978; Cunningham \& Guiry, 1986), N. multifidum (Müller \& Petronijevic, 1979), N. vermiculare (Masuda \& Horiuchi, 1988), Helminthora divaricata (Magne \& Abdel-Rahman, 1983; Cunningham \& Guiry, 1985), Helminthocladia clavadosii (Boillot, 1971a), Liagora 
distenta (Couté, 1976). Galaxauraceae-Scinaia turgida (Boillot, 1971b), Galaxaura oblongata (Magruder, 1984), Gloiophloea scinaioides (Huisan, 1987). Bonnemaisoniaceae-Asparagopsis armata (Oza, 1977), Bonnemaisonia geniculata (Shevlin \& Polanshek, 1978).

Subtype IIIb (The Acrosymphyton purpuriferum Type).

The tetrasporopohyte of Acrosymphyton purpuriferum is a crust disc composed of one to three layers of cells and resembles Hymenoclonium serpens.

It is known from Feulgen microspectrophotometric study that DNA values in gametophyte nuclei of Acrosymphyton purpuriferum are haploid, 0.358-1.026 units with an average of 0.656 units and that those of its tetrasporophyte are diploid, ranging from 0.763 to 1.902 units with a mean of 1.314 units (Breeman, 1979b).

Cryptonemiales: Dumontiaceae-Acrosymphyton purpuriferum (Cortel-Breeman \& ten Hoopen, 1978; Breeman, 1979a, b). Kallymeniaceae-Meredithia microphylla (Guiry \& Maggs, 1982b, 1984).

Subtype IIIc (The Gloiosiphonia capillaris Type).

Tetrasporophyte is crustose, a small disc or crust composed of two to several layers of cells.

Maggs (1985) demonstrated in cultures of three heteromorphic species, Atrachtophora hypnoides, Schmitzia hiscockiana and Gloiosiphonia capillaris that the ratio of erect (gametophytes) to crustose (tetrasporophytes) progenies is affected by environmental conditions during tetraspore formation and during its germination.

In Ahnfeltia plicata gonimoblast filaments grow out over the female cortex and terminate in carposporangia, showing a unique type of external carposporophyte (Maggs et al., 1988).

Nemaliales: Galaxauraceae-Nothogenia erinacea (Anderson \& Stegenga, 1985). Naccariaceae-Atrachtophora hypnoides (Maggs et al., 1983).

Cryptonemiales: Dumontiaceae-Farlowia compressa (DeCew \& West, 1981a), Dudresnaya minima (Migita \& Kawamura, 1980). Gloiosiphoniaceae-Gloiosiphonia capillaris (DeCew et al., 1981), G. verticillaris (DeCew et al., 1981).

Gigartinales: Nemastomaceae-Schizymenia dubyi (Ardré, 1977, 1980; Migita \& Kawamura, 1980), S. pacifica (DeCew, 1983). Phyllophoraceae-Ahnfeltia concinna (Magruder, 1977; Masuda, 1983), A. plicata (Chen, 1977; Maggs et al., 1988), Ahnfeltiopsis gigartinoides (DeCew, 1983), Gymnogongrus flabelliformis (Masuda et al., 1979; Masuda, 1981), G. leptophyllus (DeCew \& West, 1977a, 1981b), G. linearis (DeCew \& West, 1981b), G. furcellatus (Candia \& Kim, 1977). G. martinensis (West \& DeCew in West \& Hommersand, 1981). Gigartinaceae-Mastocarpus jardinii (West el al., 1978, as Gigartina agardhii), M. stellatus (Dion \& Delépine, 1979, as Gigartina stellata; West et al., 1977, as Gigartina stellata; Barwell et al., 1986), M. pacificum (Masuda \& Kurogi, 1981, as Gigartina ochotensis; Masuda et al., 1984, as Gigartina pacifica-ochotensis complex), M. stellatus (?) (Fletcher \& Irvine, 1982, as Petrocelis cruenta). Solieriaceae-Tumerella mertensiana (Kasahara, 1978, 1980). Callosiphoniaceae-Calosiphonia vermicularis (Mayhoub, 1973, 1975), Schmitzia hiscackiana (Maggs \& Guiry, 1985). 
Type IV (The Lemanea mamillosa Type).

The germlings of carpospores give rise to pseudochantransia plants. Apical cells of the plant undergo meiosis, which is a reduction division of vegetative cell, and then differentiate into a haploid upright plant directly. This plant develops into a gametophyte with carpogonia and spermatangia. The life history is diphasic and composed of a haploid gametophyte and a diploid carposporophyte, lacking a tetrasporophyte.

In Batrachospermum mahabaleshwarensis the gametophyte's chromosome number is 7 (haploid) and its carposporophyte 14 (diploid) (Balakrishnan \& Chaugule, 1980). In Lemanea fluviatilis meiosis occurs in the apical cells of the vegetative filament which arose from the pseudochantransia plant cells and spermatangia are haploid $(n=18-$ 19) (Thirb \& Benson-Evans, 1982). At $6^{\circ} \mathrm{C}$, the meiosis of the species takes place after the formation of diploid cladome of 30-40 segments (Huth, 1981). The pattern of karyological cycle in these species is similar to that of Lemanea reported by Magne (1967a, b), finding that the chromosome number in the lower part of the plant is 39-42, diploid and that of the upper part 20-21, haploid. From the observations that the gametophyte of Bonnemaisonia asparagoides was formed directly on. the filament of a Hymenoclonium stage derived from carpospores and that of the chromosome number of the Hymenoclonium-like plant was about 30, it is assumed that a possible site of meiosis is in the buds that give rise to upright gametophytes and that the species is of the Lemanea mamillosa type (Rueness \& Asen, 1982).

In Delisea okadai (=Ptilonia okadai) and other species which were included in type IV (the Ptilonia okadai type) in the writer's previous paper (Umezaki, 1977), the carpogonia produce carposporophytes. The carpospores, upon germination, give rise to Hymenoclonium- or crustose-like discs on which gametophytes directly develop. The life history of them has two phases, a gametophyte and a carposporophyte, lacking a tetrasporophyte. As pointed out by Morohoshi \& Masuda (1980), studying Gloiosiphonia capillaris whose upright gametophytes were directly produced from the carpospore-germling discs, it is uncertain whether the life history pattern of these species is of the direct type or apomictic, without a cytological demonstration.

Nemaliales: Lemaneaceae-Lemanea fluviatilis (Huth, 1981; Thirb \& BensonEvans, 1982). Batrachospermaceae-Batrachospermum mahabaleshwarensis (Balakrishnan \& Chaugule, 1980), B. sp. (von Stosch \& Theil, 1979). BonnemaisoniaceaeBonnemaisonia asparagoides (Rueness \& Åsen, 1982).

Type V (The Mastocarpus papillatus Type).

The female gametophytes produce carposporophytes without male gametophytes and the resulting carpospores grow into female gametophytes which produce carpospores. This type of life history has no tetrasporophytes and male gametophytes.

All the known species of Mastocarpus have this type of life history in addition to type IIIc (Guiry \& West, 1983; West et al., 1983; Masuda et al., 1984, 1987). Field female plants of Calosiphonia vermicularis also produce carposporophytes without 
fertilization by male plants (Mayhoub, 1973, 1975; Mayhoub et al., 1976). Narrowform plants of Gymnogongrus leptophyllus recycle only female gametophytes, although its wide-form plants show a life history of type IIIc (DeCew \& West, 1981b).

It has been supposed that the carposporophyte development of this type is apomictic, although no cytological evidence has been available yet. However, it is doubtful that carpospores in Mastocarpus species are produced by apomixis as pointed out by Chen et al. (1973) and Chen \& Craigie (1981) who studied carrageenan types of $M$. stellatus. According to them, the tetrasporophytes and basal discs derived from "Apomictic" carpospores contain $k$-carrageenan, whereas the upright thalli derived from these discs contain $\lambda$-carrageenan. If the chemical component of the cell wall is related to the nuclear phase in Mastocarpus, it is suggested that somatic meiosis occurs at the initiation of upright thalli. If it is true, the Mastocarpus papillatus type of life history should be amalgamated with the Lemanea mamillosa type.

Cryptonemiales: Kallymeniaceae-Cirrulicarpus carolinensis (Hansen, 1974, 1977).

Gigartinales: Gigartinaceae-Mastocarpus jardinii (West et al., 1978, as Gigartina agardhii), M. pacificus (Masuda et al., 1984, as Gigartina pacifica), M. papillatus (Polanshek \& West, 1977, as Gigartina papillata), M. stellatus (Dion \& Delépine, 1979, as Gigartina stellata; Guiry \& West, 1983, as Gigartina stellata; Rueness, 1978, as Gigartina stellata; Masuda et al., 1987, as Gigartina mamillosa sensu Mikami). PhyllophoraceaeGymnogongrus devoniensis (Ardré, 1978; McCandless et al., 1982), G. leptophyllus (DeCew \& West, 1981b). Calosiphoniaceae-Calosiphonia vermicularis (Mayhoub, 1973, 1975; Mayhoub et al., 1976).

Type VI (The Liagora tetrasporifera Type).

The short gonimoblasts derived from the divided upper cells of a fertilized carpogonium produce tetrasporangia. After liberation, the tetraspores of the sporangium grow to gametophytes. Rhodochorton subimmersum from Hokkaido, Japan, has only monoecious gametophytes on which tetrasporangia are produced, lacking an independent tetrasporophyte (Lee \& Kurogi, 1978). Lee \& Kurogi (1978) and Guiry (1987) named the gonimoblast with tetrasporangia "the carpotetrasporophyte" and "the tetrasporocysts," respectively. The former phycologists included the life history in "the Liagora tetrasporifera type" of Dixon (1973) and in type V (the Liagora tetrasporifera type) of Umezaki (1977) or in "le cycle des Nemaliales a carpotetraspores" of Magne (1972), however, Guiry (1987) referred it to "the Palmaria palmata type."

Gymnogongrus griffthsiae has been known as a species forming tetrasporoblasts on which tetrasporangia are produced (Gregory, 1934) and its life history was included in the Liagora tetrasporifera type by Dixon (1973) or in type V (the Liagora tetrasporifera type) by Umezaki (1977). A recent study of the same species by Cordeiro-Marino \& Poza (1981) showed that carposporangia are produced from both gonimoblast filaments and medullary cells with which gonimoblast filaments connected and that carpospores germinate inside the gametophyte wall and develop into tetrasporophytes appearing as external protuberances on the host alga. This seems to be a kind of 
"syntagmatic germination" seen in Pachymeniopsis yendoi (Tokida \& Yamamoto, 1965). (See part of type II).

Guiry (1988), studying the life history in culture of Liagora harveyana whose gametophyte bears carpotetrasporangia, exploded the above theory, finding that spores from the carpotetrasporangium gave rise to uniseriate, profusely branched tetrasporophytes and that tetraspores from the tetrasporophyte developed into erect multicellular fronds. According to his study, this life history is of type III (the heteromorphic type) in this paper. He emphasized from his study that species with "the Liagora tetrasporifera type" should be reinvestigated in culture.

Nemaliales: Acrochaetiaceae-Rhodochorton subimmersum (Lee \& Kurogi, 1978).

Gigartinales: Phyllophoraceae-Gymnogongrus crenulatus (Ardré, 1978), G. griffthsiae (Cordeiro-Marino \& Poza, 1981).

Type VII (The Rhodophysema elegans Type).

The crustose plant of Rhodophysema elegans has both spermatangia and carpogonia, being a bisexual gametophyte prior to fertilization. After fertilization the diploid carpogonium (zygote) divides into two unequal cells: the upper cell enlarges to become a tetrasporangium (tetrasporocyst or tetraspore mother cell) called by Magne (1982) and Guiry (1987), whereas the lower, small cell functions as a stalk cell which remains diploid. The young tetrasporangium enlarges and produces four tetraspores after meiosis. The structure of development from zygote to tetrasporangium was called a tetrasporophyte by DeCew \& West (1982). The released tetraspore germinates to give rise to a bisexual gametophyte with spermatangia and carpogonia. After fertilization the carpogonium develops into a reduced tetrasporophyte. That is, the carpogonium performs the functions of zygote and tetrasporophyte and the alga has neither an intercalary carposporophyte nor a free-living tetrasporophyte.

DeCew \& West (1982) considered that the life history of Rhodophysema elegans is the most reduced of all those known in sexually reproducing red algae.

Rhodophysema odonthaliae from Hokkaido, Japan (Masuda \& Ohta, 1981) and $R$. georgii from the Atlantic coast of Canada (Saunders \& Bird, 1989) repeat only the tetrasporophyte phase in their respective life histories and sexual structures are completely absent. On the other hand, the tetraspores of $R$. georgii from Hokkaido (Masuda \& Ohta, 1975) develop into male gametophytes or tetrasporophytes, however, the alga is devoid of a female gamesophyte.

Nemaliales: Acrochaetiaceae-Acrochaetium gynandrum (Abdel-Rahman, 1985a).

Palmariales: Palmariaceae-Rhodophysema elegans (DeCew \& West, 1982), $R$. georgii (Guiry, 1987).

Cryptonemiales: Peyssonneliaceae-Coriophyllum expansum (DeCew, 1983).

Type VIII (The Audouinella purpurea Type).

The fertilized carpogonium produces a short gonimoblast and develops into a tetrasporophyte on its gametophyte, ultimately becoming independent and fixing with its rhizoids to the substratum. The gonimoblast of this life history does not develop into a carposporophyte with carpospores. Hence, West (1969) and Guiry 
(1987) avoided the use of the term carposporophyte for the post-fertilization structure and referred to as being diphasic, whereas Magne (1972) called it a carposporophyte. Stegenga (1978) adopted more or less Magne's view and considered this life history as heteromorphic. The newly formed tetrasporophyte is much larger than the gametophyte from which the former is produced, becoming independent as mentioned above. The post-fertilization process of a gonimoblast formation in Audouinella purpurea which Ohta \& Kurogi (1979, as Rhodochorton purpureum) and Lee (1985, as Rhodochorton purpureum) studied on the materials from Hokkaido, Japan, was similar to West's (1969) and Stegenga's (1978) findings. The tetrasporophyte arising from gonimoblasts is readily distinguished under the microscope, because they are slender than that of the latter composed usually of four cells.

In Audouinella foridula (Stegenga, 1978, as Rhodochorton floridulum) and Acrochaetium gynandrum (Abdel-Rahman, 1985a) the fertilized carpogonium (zygote) divides in situ, without forming gonimoblasts, to develop into a tetrasporophyte. The life history of the two species seems to be a kind of type VIII.

Nemaliales: Acrochaetiaceae-Audouinella purpurea (Stegenga, 1978, as Rhodochorion purpureum; Ohta \& Kurogi, 1979, as Rhodochorton purpureum; Lee, 1985, as Rhodochorton purpureum), A. floridula (Stegenga, 1978, as Rhodochorton floridulum), Acrochaetium gynandrum (Abdel-Rahman, 1985a).

Type IX (The Palmaria palmata Type).

The tetraspores from a tetrasporophyte develop into female gametophytes which are extremely small and microscopic even upon maturing or into male gametophytes which are similar in size and habit to macroscopic tetrasporophytes. The female gametophyte produces carpogonia having trichogynes upon maturing. After being fertilized by spermatia from the male gametophyte, the carpogonium develops directly into a tetrasporophyte without forming a carposporophyte on its small gametophyte. The tetrasporophyte produces its own holdfast, fixing by its base and developing into a macroscopic independent plant. Macroscopically, there are male gametophytes and tetrasporophytes by which female gametophytes are covered. Hence, before the discovery of this life history the female plant of Palmaria palmata was thought to be absent.

This type of life history is diphasic: the gametophytes, although their male and female plants are much different in size, alternate with tetrasporophytes, lacking a carposporophyte completely, although having a sexual process.

Magne (1987a) considered that the generation formed from the fertilized carpogonium is not a tetrasporophyte as what was previously thought by van der Meer \& Todd (1980), van der Meer \& Chen (1979), Magne (1982) and Guiry (1987), but a carposporophyte corresponding to an independent carposporophyte of the ancestral type proposed by Feldmann in 1952. Moreover, he thought that the fertilized carpogonium develops into a parasitic tetrasporophyte. This scheme of life history, however, does not agree with van der Meer \& Todd's observations (1980).

It is karyologically known that the tetrasporophytes of Palmaria palmata (Yabu, 
1971; van der Meer, 1976), P. mollis (van der Meer \& Bird, 1985) and Devaleraea ramentacea (van der Meer \& Chen, 1979; van der Meer, 1981; Jónsson \& Chesnoy, 1982) are diploid and their vegetative gametophytes and tetraspore germlings are haploid, although their respective chromosome numbers are more or less different according to localities studied.

Palmariales: Palmariaceae-Palmaria palmata (=Rhodymenia palmata) (van der Meer \& Todd, 1980), P. mollis (van der Meer \& Bird, 1985), Halosaccion americanum (Mitman \& Phinney, 1985), Devaleracea ramentacea (=Halosaccion ramentaceum) (van der Meer, 1981).

Type X (The Hildenbrandia prototypus Type).

The only tetrasporophyte-generation is repeated in life history and the plant is diploid and its tetraspores are considered to be produced by apomeiosis. A life history in which the tetrasporophyte recycles itself by a presumed apomeiosis was demonstrated in Rhodochorton concrescens by West (1970).

In Rhodochorton membranaceum the tetrasporophyte-generation has been repeated for six years of culture, except one example in which spermatangia-like structures were borne on a plant producing tetrasporangia (West, 1979). It is assumed that in Antithamnion boreale meiosis does not take place in the tetrasporangium (Sundene, 1962) and that tetraspores of some strains in Antithamnion sarniensis are produced by apomeiosis (Megne, 1986a, 1987b). The latter species was karyologically demonstrated that tetraspores giving tetrasporophytes apomeiotically were produced and that tetraspores which gave rise to gametophytes were produced after meiosis. Chromosome number of the species was about 35 in the gametophyte and about 70 in the tetrasporophyte (Magne, 1987b). From this study, Magne assumed that the rate of apomeiosis in strains is not affected by environmental conditions, but a genetic characteristic of the strain. Some strains of Fauchea laciniata and F. pygmaea are also capable of nonsexual life history, repeating the tetrasporophyte-generation, in addition to normal sexual life history (West \& Norris, 1966).

Suneson (1950) found that Dermatolithon litorale (as Lithophyllum litorale) has no sexual plants and that its uninucleate bispores are formed without reduction of chromosome number. His result was confirmed by himself in 1982 in culture that the bispores germinated to form crustaceous plants whose conceptacles contained only bisporangia together with uninucleate bispores, as in the initial material. Chamberlain (1977) found the same result in culture that Fosliella farinosa reproduced only by bispores. Selfperpetuating bisporangial life histories are also known in Pneophyllum lobescens, $P$. zonale and $P$. plurivalidum all of which reproduce by uninucleate bispores (Chamberlain, 1987).

Nemaliales: Acrochaetiaceae-Rhodochorton membranaceum (West, 1979), R. concrescens (West, 1977).

Cryptonemiales: Hildenbrandiaceae-Hildenbrandia prototypus (DeCew \& West, 1977b), H. occidentalis (DeCew \& West, 1977b), H. crouanii (Fletcher, 1985), H. rubra (Fletcher, 1985). Corallinaceae-Dermatolithon litorale (Suneson, 1950, as Litho- 
phyllum litorale, 1982). Lithophyllum incrustans (Ford et al., 1983; Edyvean \& Ford, 1986), Fosliella farinosa (Chamberlain, 1977), Pneophyllum lobescens (Chamberlain, 1987), P. plurivalidum (Chamberlain, 1987), P. zonale (Chamberlain, 1987), Litholhrix aspergillum (Ganesan \& Desikachary, 1970).

Rhodymeniales: Rhodymeniaceae--Fauchea laciniata (West \& Norris, 1966), F. pygmaea (West \& Norris, 1966). Champiaceae-Lomentaria orcadensis (Foran \& Guiry, 1983).

Ceramiales: Ceramiaceae-Callithamnion corymbosum (Hassinger-Huizinga, 1952), Antithamnionella sarniensis (Magne, 1986a, b; L'Hardy-Halos, 1985, as Antithamnion sarniense; Sundene, 1964, as Antithamnion sarniense).

Type XI (The Audouinella pectinata Type).

The fertilized carpogonium develops directly into a carpospore without forming gonimoblasts, which was named "sporocyste" by Abdel-Rahman \& Magne (1983) and which was also interpreted as the equivalent of normally developed carposporophytes by them. The sporozygote, after releasing, develops into a tetrasporophyte upon germination. This pattern of life history is an alternation of gametophyte and tetrasporophyte phases, not intercalating a true carposporophyte phase, although sporozygotes are formed and although the life history is considered to be trigenic by Abdel-Rahman \& Magne (1983).

On an occasion the fertilized carpogonium of Audouinella pectinata formed gonimoblasts on which carposporangia were produced, forming a true carposporophyte. This type of life history belongs to type IIb. That is, this species has two types of life history, type IIb and type XI. It appears from this result that the latter type was derived from algae with the isomorphic type as a result of loss of a carposporophyte through evolution. West (1968) could not observe the fertilization of the carpogonium of the species even in culture in which male and female gametophytes were maintained for as long as six years.

The life history of Audouinella rosulata whose carpogonium does not develop into a carposporophyte is assumed to be either that of Audouinella pectinata (type XI) or that of Acrochaetium gynandrum (type IX) (Abdel-Rahman, 1985b).

Nemaliales: Acrochatiaceae-Audouinella pectinata (Abdel-Rahman \& Magne, 1983, as Acrochaetium pectinatum), A. rosulata (Abdel-Rahman, 1985b).

2. Species possessing two types of life history.

Some species in the Florideophyceae have two types of life history, according to strains, culture conditions or geographical distribution (Table 1). It is well known that Mastocarpus species have two types of life history according to strains. One is a sexual life history (type IIIc) and the other is a apomictic life history (type V) (Guiry \& West, 1983; West et al., 1983; Masuda et al., 1984, 1987). There is a clear latitudinal distributional pattern of type IIIc and type $\mathrm{V}$ in Mastocarpus stellatus (Guiry \& West, 1983) and in M. papillatus (Zupan \& West, 1988). The frequency of type IIIc increases in the southern localities of its geographical range, while that 
Table 1. Species possessing two types of life history

\begin{tabular}{llll}
\hline \multicolumn{1}{c}{ Species } & Types & \\
\cline { 2 - 4 } Nemaliales & & & References \\
Acrochaetium gynandrum & IIb & IX & Abdel-Rahman, 1985a \\
Audouinella pectinata & IIb & XI & Abdel-Rahman \& Magne, 1983 \\
Audouinella rosulata & IX & XI & Abdel-Rahman, 1985b \\
Atractophora hypnoides & IIIb & X & Maggs et al., 1983; Maggs, 1985 \\
Cryptonemiales & & & \\
Dermatolithon corallinae & IIa & X & Suneson, 1950, as Lithophyllum corallinae \\
Lithophyllum incrustans & IIa & X & Edyvean \& Ford, 1986; Ford et al., 1983 \\
Lithothrix aspergillum & IIa & X & Ganesan \& Desikachary, 1970 \\
Gloiosiphonia capillaris & IIIb & X & DeCew et al., 1981; Maggs, 1985 \\
Gigartinales & & & \\
Calosiphonia vermicularis & IIIc & V & Mayhoub, 1973; Mayhoub et al., 1976 \\
Gardneriella tuberifera & IIa & X & Goff, 1981 \\
Gymnogongrus leptophyllum & IIIc & V & DeCew \& West, 1981b \\
Mastocarpus jardinii & IIIc & V & West et al., 1978, as Gigartina agardhii \\
Mastocarpus pacificus & IIIc & V & Masuda et al., 1984, as Gigartina pacifica \\
Mastocarpus stellatus & IIIc & V & Guiry \& West, 1983, as Gigartina stellata \\
Schmitzia hiscockiana & IIIb & X & Maggs, 1985; Maggs \& Guiry, 1985 \\
Rhodymeniales & & &
\end{tabular}

of type $\mathrm{V}$ increases toward the north. From the fact that tetraspore germlings grew directly into tetrasporophytes without proceeding to gametophytes, Masuda et al. (1984) assumed that the direct type has been derived from individuals with the heteromorphic type. Lithophyllum incrustans is another example: in British Isles there are two types of spores, bispores and tetraspores on its asexual plants. The northern population at Cullercoats has mostly plants producing bispores (an average of $96.2 \%$ ) (type X), while the plants from the southern population at Lannacombe Bay produce tetraspores (80.9\%) (type II) and with only a small percentage producing bispores $(16.6 \%)$. The asexual phase producing bispores is repeated in the northern areas at the edge of distribution and the bispores are produced by apomixis (Edyvean \& Ford, 1986).

Some unusual phenomena in the life history or "mixed-phase" which is a term used by van der Meer \& Todd (1977) for red algae have been found. Antithamnion occidentalis, A. pygmaea and Platythamnion sp. produced tetrasporangia on their respective gametophytes (West \& Norris, 1966), while Spermothamnion repens (Drew, 1934, as Spermothamnion turneri), Audouinella floridula (Knaggs, 1965, as Rhodochorton floridulum), Antithamnion defectum and Callithamnion sp. had spermatangia on their respective tetrasporophytes (West \& Norris, 1966). West (1979) supposed that in the latter's life 
history the occurrence of gametophytes and carposporophytes was suppressed during the course of evolution of life history.

Similar mixed phases were found on Antithamnion boreale (Sundene, 1962), Audouinella membranacea (West, 1979, as Rhodochorton membranaceum), Callithamnion baileyi (Whittick \& West, 1979), C. bipinnatum (Rueness \& Rueness, 1980), C. byssoides (Rueness \& Rueness, 1980), C. tetragonum (Rueness \& Rueness, 1985), Symphyocladia pennata (Choi \& Lee, 1987), Dasysiphonia chejuensis (Choi \& Lee, 1988), Bosirychia tenella (West \& Calumpong, 1988a) and Dawsoniocolax bostrychiae (West \& Calumpong, 1988b). Jania rubens has sometimes a modified isomorphic type: the tetraspores develop into monoecious gametophytes and their carpospores grow up to plants bearing both spermatangia and tetrasporangia (von Stosch, 1969).

In Europe some marine red algae lose their one or two phases of life history at their northern limits of distribution, persisting as gametophytes (haploid) or tetrasporophytes (diploid), or they become completely sterile and maintain their population by vegetative reproduction and/or fragmentation (Dixon, 1965; Guiry \& Cunningham, 1983). For example, Callithamnion corymbosum reproduces by vegetative fragmentation and by tetraspores from tetrasporophytes (Whittick, 1978). Nakahara \& Masuda (1971) reported that species of the green and brown algae which have heteromorphic life histories increases relatively toward the northern localities in Japan or with the lowering of the mean annual seawater temperature. In species with the isomorphic life history type the different life history phases, haploid male and female gametophytes and diploid tetrasporophytes show no conspicuous differences in physiological performances such as net photosynthesis, calorific value or resistence to predation (Littler et al., 1987), or in growth optimum to temperature, light intensity, water movement and salinity (Hannach \& Santelices, 1985).

3. Evolutionary paths among life history types.

In 1952 Feldmann proposed that the ancestral type of life history in the Florideophyceae had three phases of generation, gametophyte-, carposporophyte- and tetrasporophyte-phases, each of which was of an independent growth and that the Polysiphonia type in the existing red algae was derived from algae with the ancestral type by the parasitism of carposporophyte through an evolutionary path. In accordance to Feldmann's hypothesis Magne (1972) and Umezaki (1977) proposed that the various types of life history were derived from algae with the Polysiphonia type, the primitive type in the existing red algae in the class through different courses of evolution. This theory is also accepted in the present paper (Fig. 1).

Magne (1987a) considered that the foliose tetrasporophyte of Palmaria palmata is an independent carposporophyte corresponding to ancestral carposporophyte of Feldmann's hypothesis.

The carposporophyte of the ancestral type (type I) became endophytic in a gametophyte from which it takes nutrients, ultimately becoming parasitic. This is a birth of type II with independent gametophyte and tetrasporophyte phases both of which are morphologically almost identical and a parasitic carposporophyte. 


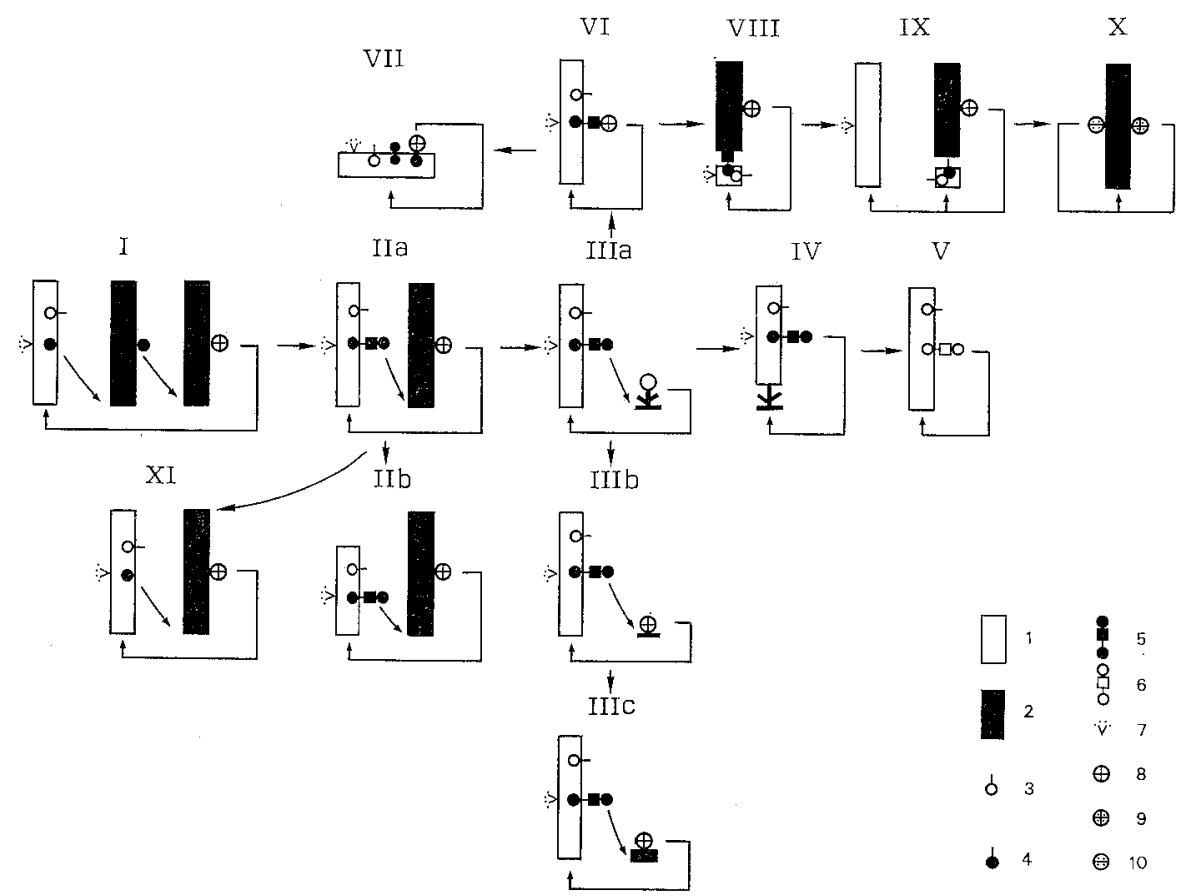

Fig. 1. Life history types in the Floridoephyceae and their evolutionary paths. A course: type $\mathrm{I} \rightarrow$ type IIa $\rightarrow$ type IIIa $\rightarrow$ type IV $\rightarrow$ type V; B course: type $\mathrm{IIa} \rightarrow$ type IIIa $\rightarrow$ type VI $\rightarrow$ type VII; C course: type IIa $\rightarrow$ type IIIa $\rightarrow$ type VI $\rightarrow$ type VIII $\rightarrow$ type IX $\rightarrow$ type $\mathrm{X}$; D course: type IIa $\rightarrow$ type XI. 1, haploid gametophyte; 2, diploid sporophyte; 3, non-fertilized carpogonium; 4, fertilized carpogonium; 5, fertilized carpogonium and diploid carposporophyte; 6, non-fertilized carpogonium and haploid carposporophyte; 7, spermatangia; 8 , tetrasporangium with four meiospores; 9 , tetrasporangium with four apomixis spores; 10 , bisporangium with two apomixis spores.

The tetrasporophyte of type II reduced its size to become a form different from its gametophyte: the newly born type (type III) has developed into three subtypes, subtype IIIa (the Bonnemaisonia hamifera type), subtype IIIb (the Acrosymphyton purpuriferum type), and subtype IIIc (the Gloiosiphonia capillaris type). The tetrasporophyte of algae derived from type III became a protonema of its gametophyte, losing its independence and sprouting a haploid gametophyte after vegetative meiosis. Through this process of evolution type IV was derived from algae of type III. The carpogonium of type IV produced a carposporophyte without the fertilization by spermatia, losing completely its sexuality. As the result, the derived algae lost a sporophyte phase from their life history. The newly born type of life history is type V. This was born through an evolutionary course of type II, type III and type IV. This regeneration path of tetrasporophyte and ultimately the loss of sporophyte phase are named "A course."

The tetrasporophyte phase of type III lost its independence, becoming parasitic on the gonimoblasts of a gametophyte on which tetrasporangia were produced. That is, the gonimoblasts of algae derived from type III evolved into a carposporo- 
phyte (or tetrasporoblast) with a function of both gonimoblast and primitive tetrasporophyte. The plant thus formed is of type VI. The parasitic carposporophyte (or tetrasporoblast) of some algae derived from type VI reduced into one-celled tetrasporophyte (or tetrasporangium). This is a birth of type VII. The tetrasporophyte phase was lost during the evolutional process from type VI to type VII. This is named "B course" of evolutional path. The parasitic gonimoblasts of another algae derived from type VI developed directly into a tetrasporophyte and became independent, although its base was attached on the gametophyte from which it gets nutrients during its young stage. Thus, a new type of life history (type VIII) was born. West (1969) suggested that the tetrasporophyte of this type may be a parasitic stage in the process of becoming an independent tetrasporophyte. Type IX was derived from algae of type VIII: after fertilization, a carpogonium germinated in situ without forming gonimoblasts on its gametophyte to grow into a tetrasporophyte, which is implanted on a minute gametophyte from which it was derived. And, the gonimoblast became greatly reduced in vegetative size and function, becoming microscopic, although sexual process is retained. This is type IX. Magne (1987a), however, considered that the tetrasporophyte of type IX (the Palmaria palmata type) is a living carposporophyte and that the tetrasporophyte was evolutionally degenerated as in Rhodophysema elegans whose tetrasporophyte is parasitic. An evolutional path from type VIII to type IX may be said to be a vegetative degeneration of female gametophyte, retaining tetrasporophyte semiparasitically. Algae derived from those of type IX retained only tetrasporophyte, losing a sexual phase of life history. The diploid plant produces apomeiotic tetraspores or rarely uninucleate bispores by which sporophyte generation is repeated. Algae producing uninucleate bispores were born from algae producing apomeiotic tetraspores. An evolutional path ( $\mathrm{C}$ course) from type VI through type VIII and type IX to type X was a loss of two phases, carposporophyte and gametophyte, retaining only a single phase, sporophyte. Retaining of sporophyte is most stable in the living Florideophyceae, because it can keep progenies by non-sexual spores.

The gonimoblast formation of a carposporophyte was lost from algae derived from type II and it became one-celled carposporophyte with a single carpospore. This is the simplest carposporophyte in the class. Thus, type XI was born. This evolutional course is named "D course." The occurrence of this type suggests the possibility of absence of carposporophyte in the existing red algae.

4. Comparison between systematic orders and types of life history.

Umezaki (1977) concluded that types of life history, which were classified into nine categories, did not agree with the phylogenetic orders in the Florideophyceae. The present paper classifies the life histories of the class into 11 types of which three are newly added to the types reported by Umezaki (1977). Table 2 shows the relationship between the systematic orders in the class and types of life history, from which the followings would be concluded.

1) The life history patterns of the Nemaliales are most variable in the class, 
Table 2. Relationship between systematic orders and life history types in the Florideophyceae

\begin{tabular}{|c|c|c|c|c|c|c|c|}
\hline & Nemaliales & Gelidiales & Palmariales & $\begin{array}{l}\text { Crypto- } \\
\text { nemiales }\end{array}$ & Gigartinales & Rhodymeniales & Ceramiales \\
\hline II & + & + & & + & + & + & + \\
\hline III & + & & & + & + & & \\
\hline IV & + & & & & & & \\
\hline $\mathrm{V}$ & & & & + & + & & \\
\hline $\mathrm{VI}$ & + & & & & + & & \\
\hline VII & + & & + & & & & \\
\hline VIII & + & & & & & & \\
\hline IX & & & + & & & & \\
\hline $\mathrm{X}$ & + & & & + & & + & + \\
\hline $\mathrm{XI}$ & + & & & & & & \\
\hline Total & 8 & 1 & 2 & 4 & 4 & 2 & 2 \\
\hline
\end{tabular}

possessing eight types from the primitive type, type II, to the all advanced types except type V and type IX. 2) Orders Cryptonemiales and Gigartinales have four types and the type II, type III and type $V$ are common to the two orders. 3) The Palmariales, which was established by Guiry (1978; Guiry \& Irvine, 1981), has type VII and type IX, among them type IX being peculiar to the class, because of the absence of a carposporophyte and the presence of reduced female gametophyte. 4) The Rhodymeniales and the Ceramiales have each two types, type II and type X. 5) The Gelidiales, although this order is recently included in the Nemaliales (Dixon \& Irvine, 1977), has a single type, type II. 6) Type II, the most primitive type is found in the all orders except the order Palmariales and type $\mathrm{X}$ is known in four orders except Gelidiales, Palmariales and Gigartinales.

\section{Acknowledgments}

I express my cordinal thanks to Dr. John A. West, University of California, Berkeley and Dr. Michio Masuda, Hokkaido University, Sapporo, for critical reading of the manuscript.

\section{References}

Abdel-Rahman, M.-H. 1980. La morphologie et le cycle de développement de 1'Acrochaetium subtillissimum (Rohdophycées, Acrochaetiales). Cryptogamie, Algol., 1: 99-100.

- 1981. Le cycle de développement de 1'Acrochaetium unifilum (Rhodophycée, Acrochaetiales). Ibid., 2: 241-252.

- 1985a. Le cycle de développement de 1'Acrochaetium gynandrum (Rhodophycée, Acrochaetiales). Ibid., 6:1-12.

- 1985b. Le cycle de développement de l'Audouinella rosulata (Rhodophycées, Acrochaetiales). Ibid., 6: 171-184.

- \& F. Magne. 1981. Le cycle de développement de l'Acrochaetium asparagopsis (Rhodophycées, Acrochaetiales). Ibid., 2: 163-170.

- \& 1983 . Existence d'un nouveau type de cycle de développement chez les Rhodophycées. C.R. Acad. Sci. Paris, Sér. III, 296: 641-644. 
\& - 1984. Le développement de l'Acrochaetium boryanum sp. nov. (Rhodophycée, Acrochaetiales). Cah. Biol. Mar., 24: 1-14.

Anderson, R.T. \& H. Stegenga. 1985. A crustose tetrasporophyte in the life history of Nothogenia erinacea (Turner) Parkinson (Galaxauraceae, Rhodophyta). Phycologia, 24: 111-118.

Aponte, N.E. \& D.L. Ballantine. 1987. The life history and development of Murrayella periclados (G. Agardh) Schmitz (Rhodophyta, Rhodomelaceae) in culture. Gryptogamie, Algol., 8: 29-39.

Ardré, F. 1977. Sur le cycle du Schizymenia dubyi (Chauvin ex Dubyi) J. Agardh (Nemastomacées, Gigartinale). Rev. Algol., n.s., 12: 73-86.

- 1978. Sur le cycles morphologiques du Gymnogongrus crenulatus (Turn.) J. Ag. et du Gymnogongrus devoniensis (Grev.) Schott (Gigartinales, Rhodophycées) en culture. Ibid., 13: 151-176.

- 1980. Observations sur de développement du Schizymenia dubyi (Rhodophycée, Gigartinale) en culture. Cryptogamie, Algol., 2: 111-140.

Athanasiadis, A. 1983. The life history of Antithamnion heterocladum (Rhodophyta, Ceramiales) in culture. Bot. Mar., 26: 153-157.

- 1985. The taxonomic recognition of Pterothamnion crispum (Rhodophyta, Ceramiales), with a survey of the carposporophyte position in genera of the Antithamnieae. Br. Phycol. J., 20:381-389.

Balakrishnan, M.S. \& B.B. Chaugule. 1980. Cytology and life history of Batrachospermum mahabaleshwarensis Balakrishnan et Chaugule. Cryptogamie, Algol., 1: 83-97.

Ballantine, D.L. 1988. Botryocladia life histories in laboratory culture. Abst. 3rd Int. Phycol. Congr., Melbourne: 3 .

- \& M.J. Wynne. 1988. The life hsitory and development of Hypoglossum rhizophorum (Delesseriaceae, Rhodophyta) in culture, a new deep-water species from the Caribbean. J. Phycol., 24: 8-12.

Barwell, C.J., R.L. Fletcher, L.M. Irvine, G.A. Maggs \& W.F. Prud'homme van Reine. 1986. The hordenine content of Petrocelis cruenta and Petrocelis hennedyi. Br. Phycol. J., 21: 325.

Bodard, M. 1966. Sur le développement des tetrasporocystes d'Anatheca montagnei Schmitz (Solieriacées, Gigartinales). Bull. de l'I.F.A.N. 28, sér, A, 3: 867-894.

Boillot, A. 1971a. Sur le cycle d'Helminthocladia clavadosii (Lamouroux) Setchell. Bull. Soc. Phycol. Fr., 16: 106-110.

—_. 1971b. Sur le cycle de Scinaia turgida Chemin. Ibid., 16: 68-69.

Boo, S.M. \& I.K. Lee. 1983. A life history and hybridization of Antithamnion sparsum Tokida (Rhodophyta, Ceramiaceae) in culture. Korean J. Bot., 26: 141-150.

Borsje, W.J. 1973. The life hsitory of Acrochaetium virgatulum (Harvey) J. Ag. in culture. Br. Phycol. J., 8: 204-205.

Breeman, A.M. 1979a. The life history and its environmental relation in the subtidal red alga $A c-$ rosymphyton purpuriferum (J. Ag.) Sjöst. 141 pp. Dr. Thesis, the Rijksuniversity, Leiden.

- 1979b. The cytological phases in the life history of Acrosymphyton purpuriferum (J. Ag.) Sjöst. (Rhodophyceae, Cryptonemiales). Phycologia, 18: 146-148.

Brodie, J. \& M.D. Guiry, 1986. Life history and morphology of Botryocladia boergesenii (Rhodophyta) from Portugal. Br. Phycol. J., $21: 327$.

\& - 1987. Life history and photoperiodic responses in Cordylecladia erecta (Rhodophyta) from Ireland. Ibid., 22: 300-301.

- \& 1988a. Life history and reproduction of Botryocladia ardreana sp. nov. (Rhodymeniales. Rhodophyta) from Portugal. Phycologia, 27: 109-130.

- 1 - 1988b. Life history and reproduction of Cordylecladia erecta (Rhodymeniaceae, Rhodophyta). Br. Phycol. J., 23: 347-364.

Candia, A.I. \& D.H. Kim. 1977. Resultados preliminares de los estudios de ciclo de vida de Gymnogongrus furcellatus (C. Agardh) J. Agardh (Phyllophoraceae, Gigartinales). Gayana Miscelanea, No. 5, Primeras J. Nacion Agricultura, pp. 77-78.

Chamberlain, Y.M. 1977. Observations on Fosliella farinosa (Lamour.) Howe (Rhodophyta, Corallinaceae) in the British Isles. Br. Phycol. J., 12: 343-358.

- 1987. Conceptacle production and life history in four species of Pneophyllum (Rhodophyta, 
Corallinaceae) from the British Isles. Ibid., 22: 43-48.

Chen, L.G.-M. 1977. The sporophyte of Ahnfeltia plicata (Huds.) Fries (Rhodophyceae, Gigartinales) in culture. Phycologia, 16:163-168.

— \& J.S. Graigie. 1981. Carrageenan analysis in apomicitc Gigartina stellata-New puzzles. Proc. 10th Int. Seaweed Symp., Göteborg: 391-396.

- T. Edelstein, G. Brid \& Y. Yabu, 1978. A culture and cytological study of the life history of Nemalion helminthoides (Rhodophyta, Nemaliales). Proc. N.S. Inst. Sci., 28: 191-199.

\& J. McLachlan. 1979. Rhodoglossum affine (Harv.) Klyin (Gigartinaceae, Rhodophyta) in culture. Syesis, 12: 113-116.

- - - A.C. Nelsh \& P.F. Shacklock. 1973. The ration of kappa- to lambda-carrageenan in nuclear phases of the rhodophycean algae, Chondrus crispus and Gigartina stellata. J. Mar. Biol. Ass. U.K., 53: 11-16.

Choi, D.S. \& I.K. Lee. 1987. Symphyocladia pennata Okamura (Rhodophyta, Rhodomelaceae) in Korea. Korean J. Phycol., 2: 173-183.

\& I.K. Lee. 1988. An unusual reproduction of Dasysiphonia chejuensis Lee et West (Dasyaceae, Rhodophyta) in culture. Abst. 3rd Int. Phycol. Congr., Melbourne: 9.

Cordeiro-Marino, M. \& A.C. Poza. 1981. Life history of Gymnogongrus griffthsiae (Turner) Martius (Phyllophoraceae, Gigartinales). Proc. 10th Int. Seaweed Symp., Göteborg: 155-161.

Cormaci, M. \& G. Motta. 1985. Observationi su Lophocladia lallemandii (Mont.) Schmitz (Ceramiales, Rhodomelaceae) in culture. Boll. Acc. Gioenia Sci. Nat., 18: 797-808.

Cortel-Breeman, A.M. \& A. ten Hoopen. 1978. The short day response in Acrosymphyton purpuriferum (J. Ag.) Sjöst. (Rhodophyceae, Cryptonemiales). Phycologia, 17: 125-132.

Couté, A. 1976. Etude comparative des cycles du Liagora tetrasporifera Boerg. et du Liagora distenta (Mert.) C. Ag. en culture. Rev. Algol., n.s., 11 : 273-297.

Gunningham, E.M. \& M.D. Guiry. 1985. Photoperiodic and temperature control in the life history of Helminthora divaricata (Rhodophyta) from Ireland. Abst. 2nd Int. Phycol. Congr., Copenhagen: 34.

\& M.D. Guiry. 1986. Effects of nutrient concentration and the development and reproduction of Nemalion helminthoides (Rhodophyta) in culture. Br. Phycol. J., 21: 327.

DeCew, T.C. 1983. Culture studies in the Hildenbrandiales, Cryptonemiales and Palmariales (Rhodophyta). Ph. D. Thesis, 208 pp., Univ. California, Berkeley.

— \& J.A. West. 1977a. Life history relationship between Gymnogongrus leptophyllus and Erythrodermis (=Petrocelis) haematis. Br. Phycol. J., 12: 78.

— \& J.A. West. $1977 \mathrm{~b}$. Culture studies on the marine red algae Fildenbrandia occidentalis and. H. prototypus (Cryptonemiales, Hildenbrandiaceae). Bull. Jap. Soc. Phycol., 25 (Suppl.): 31-41.

\& 1981a. Investigations on the life histories of three Farlowia species (Rhodophyta: Gryptonemiales, Dumontiaceae) from Pacific North America. Phycologia, 20: 342-351.

- \& 1981 b. Life histories in the Phyllophoraceae (Rhodophyta: Gigartinales) from the Pacific coast of North America. I. Gymnogongrus linearis and G. leptophyllus. J. Phycol., 17: $240-250$.

\& 1982 . A sexual life history in Rhodophysema: a reinterpretation. Phycologia, $21: 67-74$.

_- \& E.K. Ganesan. 1981. The life history and developmental morphology of two species of Gloiosiphonia (Rhodophyta: Cryptonemiales, Gloiosiphoniaceae) from the Pacific coast of North America. Ibid., 20: 415-423.

Dion, P. \& R. Delépine. 1979. Cyycles de développement de Gigartina stellata et Petrocelis cruenta (Rhodophyceae, Gigartinales) etudies in situ, a Roscoff. Rev. Algol., n.s., 14: 327-341.

Dixon, P.C. 1965. Perennation, vegetative propagation and algal life histories, with special reference to Asparagopsis and other Rhodophyta. Bot. Gothoburg, 3:67-74.

-1973. Biology of the Rhodophyta, 285 pp. Oliver \& Boyd, Edinburgh.

- 1982. Life histories in the Florideophyceae with particular reference to the Nemaliales sensu lato. Bot. Mar., 25: 611-621.

\& L.M. Irvine. 1977. Seaweeds of the British Isles. Vol. 2. Rhodophyta. Part I. Intro- 
duction, Nemaliales, Gigartinales. 252 pp. British Museum (Natural History), London.

Drew, K.M. 1934. Contributions to the cytology of Spermothamnion turneri (Mert.) Aresch. I. The diploid generation. Ann. Bot., Lond., 48: 549-573.

Edwards, P. 1979. A cultural assessment of the distribution of Callithamnion hookeri (Dillw.) S.F. Gray (Rhodophyta, Ceramiales) in nature. Phycologia, 18: 251-263.

Edyvean, R.G.J. \& F. Ford. 1986. Spore production by Lithophyllum incrustans (Corallinales, Rhodophyta) in the British Isles. Br. Phycol. J., 21: 255-261.

Feldmann, J. 1952. Les cycles de reproduction des algues et leurs rapports avec la phylogénie. Rev. Cytol. Biol. Vég., 13: 1-49.

Fletcher, R.L. 1985. Studies on Hildenbrandia from the south coast of England. Br. Phycol. J., 18: 203.

_ \& L.M. Irvine. 1982. Some preliminary observations on the ecology, structure and taxonomic position of Pelrocelis hennedyi (Harv.) Batters (Rhodophyta) in Britain. Bot. Mar., 25: 601-609.

Foran, G.F. \& M.D. Guiry. 1983. The life history in culture of isolates of Lomentaria orcadensis (Rhodophyta) from Ireland and Scotland. Br. Phycol. J., 18: 204.

Ford, H., F.A. Hardy \& R.G.J. Edyvean. 1983. Population biology of the crustose red alga Lithophyllum incrustans Phil. Three populations on the east coast of Britain. J. Linn. Soc., Biol., 23: 353-363.

Ganesan, E.K. \& T.V. Desikachary. 1970. Studies on the morphology and reproduction of the articulated corallines. -V. Lithothrix Gray. Phykos, 9: 41-51.

Garbary, D.J., D.W. Grund \& J. McLachlan. 1978. The taxonomic status of Ceramium rubrum (Huds.) C. Ag. (Ceramiales, Rhodophyceae) based on culture experiments. Phycologia, 17: 85-94.

- D.W. Grund \& J. McLachlan. 1980. Branching patterns and life history stages in Ceramium rubrum (Huds.) G. Ag. Nova Hedwigia, 33: 249-260.

Goff, L.J. 1981. The role of bispores in the life history of the parasitic red alga, Gardneriella tuberifera (Solieriaceae, Gigartinales). Phycologia, 20: 397-406.

_ \& K. Cole. 1976. The biology of Harveyella mirabilis (Cryptonemiales, Rhodophyceae). IV. Life history and phenology. Can. J. Bot., 54: 281-292.

Gregory, B.D. 1934. On the life history of Gymnogongrus griffithsiae Mart. and Ahnfeltia plicata Fries. J. Linn. Soc., Bot., 49: 127-137.

Guiry, M.D. 1978. The importance of sporangia in the classification of the Florideophyceae. In: D.E.G. Irvine \& J.H. Prince, eds., Modern Approaches to the Taxonomy of Red and Brown Algae, pp. 111-144. Academic Press, London \& New York.

. 1987. The evolution of life history types in the Rhodophyta: an appraisal. Cryptogamie, Algol., 8: 1-12.

-1988. The life history of Liagora harveyana (Rhodophyta) from Australia. Abst. 3rd Int. Phycol. Congr., Melbourne: 15.

- \& E.M. Cunningham. 1983. Life history and photoperiodism in culture of Gigartina acicularis (Rhodophyta) from England and France. Br. Phycol. J., 18: 204.

— \& D.E.G. Irvine. 1981. A critical reassessment of infraordinal classification in the Rhodymeniales. Proc. 8th Int. Seaweed Symp., Bangor: 106-111.

_ \& C.A. Maggs. 1982a. The morphology and life history of Dermocorynus montagnei Crouan frat. (Halymeniaceae; Rhodophyta) from Ireland. Br. Phycol. J., 17: 215-228.

_ \& - 1982b. The life history of Meredithia microphylla (J. Ag.) J. Ag. (Rhodophyta) in culture. Ibid., 17: 232-233.

- \& 1984. Reproduction and life history of Meredithia microphylla (J. Ag.) J. Ag. (Kallymeniaceae, Rhodophyta) from Ireland. Giorn. Bot. Ital., 118: 105-125.

— \& J.A. West. 1983. Life history and hybridization studies on Gigariina stellata and Petrocelis cruenta (Rhodophyta) in the North Atlantic. J. Phycol., 19: 474-494.

Hannach, G. \& B. Santelices. 1985. Ecological differences between the isomorphic reproductive phases of two species of Iridaea (Rhodophyta: Gigartinales). Mar. Ecol. Prog. Ser., 22: 291-303.

Hansen, G.I. 1974. A morphological and life history study of a new species of Cirrulicarpus (Kallymeniaceae, Rhodophyta) from North California. J. Phycol,, 10(Suppl.): 4. 
1977. Cirrulicarpus carolinensis, a new species in the Kallymeniaceae (Rhodophyta). Occas. Pap. Farlow Herb. Cryptogam. Bot. Harv. Univ., 12: 1-22.

Hassinger-Huizinga, H. 1952. Generationswechsel und Geschlechtbestimmung der Callithamnion corymbosum (Sm.) Lyngb. Arch. Protestenk., 98: 91-124.

Huisan, J.A. 1987. The taxonomy and life history of Gloiophloea (Galaxauraceae, Rhodophyta). Phycologia, 26: 167-174.

Huth, K. 1981. Der Generationswechsel von Lemanea fluviatilis C. Ag. in Kultur. Nova Hedwigia, 34: $177-189$.

Jónsson, S. \& L. Chenoy. 1982. Étude du cycle chromosomique de l'Halosaccion ramentaceum (Rhodophyta, Palmariales) d'Iceland. Cryptogamie, Algol., 3: 273-278.

Kapraun, D.F. 1977. Sexual propagation in the life history of Polysiphonia ferulacea (Rhodophyta, Ceramiales). Phycologia, 16: 417-426.

Kasahara, K. 1978. The life history of Turnerella mertensiana. Proc. 43rd Annual Meet., Bot. Soc. Jap., 1980: 92.

- 1980. On the life history of Turnerella mertensiana (Rhodophyta, Gigartinales). Bot. Mag., Tokyo, 93: 117-123.

Knaggs, F.W. 1965. Spermatangia on the tetrasporophyte of Rhodochorton floridulum (Dillw.) Näg. Nova Hedwigia, 10: 269-272.

Kornmann, P. \& P.-H. Sahling. 1980. Kalkbohrende Mikrothalli bei Helminthocladia und Scinaia (Nemaliales, Rhodophyta). Helgoländer Meeresunters., 34: 31-40.

Kudo, T. \& M. Masuda. 1986. A taxonomic study of Polysiphonia japonica Harvey and P. akkeshiensis Segi. Jap. J. Phycol., 34: 293-310.

Lee, I.K. \& J.A. West. 1980a. A life history of Lomentaria hakodatensis Yendo (Rhodophyta, Lomentariaceae) in culture. Bot. Mar., 23: 419-423.

—— \& 1980b. Antithamnion nipponicum Yamada et Inagaki (Rhodophyta, Ceramiales) in culture. Jap. J. Phycol., 28: 19-27.

- - \& M. Hommersand. 1981. Binghamiopsis caespitosa gen. et sp. nov. (Lomentariaceae, Rhodophyta) from the eastern Pacific. In: C.S. Lobban \& M.J. Wynne, eds., The Biology of Seaweeds, pp. 133-193. Blackwell, Oxford.

Lee, Y.P. 1985. Notes on reproduction in Rhodochorton purpureum (Lightfoot) Rosenvinge (Rhodophyta) with special reference to Hokkaido plants. Korean J. Bot., 28: 45-55.

\& M. Kurogi. 1978. Sexual reproductive structures and postfertilization in Rhodochorton subimmersum Setchell et Gardner. Jap. J. Phycol., 26: 115-119.

\& 1983. The life history of Audouinella alariae (Jonsson) Woelkerling (Rhodophyta, Acrochaetiaceae) in nature and culture. J. Fac. Sci., Hokkaido Univ., Ser. V, 13: 57-76.

L'Hardy-Halos, M.-Th. 1985. Les Ceramiacées (Rhodophycées) des côtes de Bretagne, II. Particularites biologique de l'Antithamnion sarniense (Lyle)G. Feldmann et de l'A. spirographidis Schiffner. Rev. Cytol. Biol. Vég., Bot., 8: 89-116.

Littler, M.M., D.S. Littler \& P.R. Taylor. 1987. Functional similarity among isomorphic life-history phases of Polycavernosa debilis (Rhodophyta, Gracilariaceae). J. Phycol., 23: 501-505.

Macler, B.A. \& J.A. West. 1987. Life history and physiology of the red alga, Gelidium coulteri, in unialgal culture. Aquaculture, 61: 281-293.

Maggs, C.A. 1985. Environmental regulation of tetrasporophyte recycling in some heteromorphic red algae. Abst. 2nd Int. Phycol. Congr., Copenhagen: 100.

- \& M.D. Guiry. 1982. Morphology, phenology and photoperiodism in Halymenia latifolia Kütz. (Rhodophyta) from Ireland. Bot. Mar., 25: 585-599.

- \& 1985 . Life history and reproduction of Schmitzia hiscockiana sp. nov. (Rhodophyta, Gigartinales) from the British Isles. Phycologia, 24: 297-310.

- - \& L.M. Irvine. 1983. The life history in culture of an isolate of Rhododiscus pulcherrimus (Naccariaceae, Rhodophyta) from Ireland. Br. Phycol. J., 18: 206.

- G.M. Pueschel \& J.L. McLachlan. 1988. A sexual life history in Ahnfeltia plicata (Rhodophyta: Ahnfeltidiales ord. nov.). Abst. 3rd Int. Phycol. Congr., Melbourne: 27.

Magne, F. 1961. Sur le cycle cytologique du Nemalion helminthoides (Velley)Batters. C.R. Acad. 
Sci. Paris, Sér. D, 252: 157-159.

- 1967a, Sur l'existence, chez les Lemanea (Rhodophycées, Nemalionales), d'un type de cycle de développement encore inconnu chez les Algues rouges. Ibid., 264: 2632-2633.

- 1967b. Sur le découlement et le lieu de la méiose chez Lemaneacées (Rhodophycées, Nemalionales). Ibid., 265: 670-673.

- 1972. Le cycle de développement des Rhodophycées et son evolution. Soc. Bot. Fr., Mém., 1972: 247-268.

- 1977. La reproduction sexuée chez l'Acrochaetium asparagopsis (Chemin) Papenfuss, Rhodophycées. Rev. Algol., n.s., 12: 61-72.

. 1982. On two new types of life history in the Rhodophyta. Cryptogamie, Algol., 3: 265271.

- 1986a. Anomalies du developpement chez Antithamnionella sarniensis (Rhodophyceae, Ceramiaceae). II. Nature de individus issues des tetraspores. Ibid., 7: 215-229.

. 1986b. The rate of apomeiosis in the Rhodophyta, a genetical character. Abst. 12th Int. Seaweed Symp., San Paulo: 71.

-1987a. La tetrasporogenese et le cycle de développement des Palmariales (Rhodophyte): une nouvelle interprétation. Cryptogamie, Algol., 8: 273-280. 1987b. Is the frequency of apomeiosis in the Rhodophyta a genetic character? Hydrobio-
logia, $151 / 152: 221-222$.
— \& M.-H. Abdel-Rahman. 1983. La nature exacte de I'Acrochaetium polyides (Rhodophy- cées, Acrochaetiales). Cryptogamic, Algol., 4: 21-35.

Magruder, W.H. 1977. The life history of the red alga Ahnfeltia concinna (Rhodophyta, Gigartinales). Phycologia, 16: 197-203.

-1984. Reproduction and life history of the red alga Galaxaura oblongata (Nemaliales, Galaxauraceae). J. Phycol., 20: 402-409.

Masuda, M. 1981. Further observations on the life history of Gymnogongrus flabelliformis Harvey (Rhodophyta) in culture. J. Fac. Sci., Hokkaido Univ., Ser. V, 12: 159-164.

1982. A systematic study of the tribe Rhodomeleae (Rhodomelaceae, Rhodophyta). Ibid., 12 : 209-400, pls. $1-28$.

- 1983. The life history of Ahnfeltia concinna J. Agardh (Rhodophyta, Gigartinales) from Japan. Jap. J. Phycol., 31: 180-189.

, T.C. DeCew \& J.A. West. 1979. The tetrasporophyte of Gymnogongrus flabelliformis Harvey (Gigartinales, Phyllophoraceae). Ibid., 27:63-73.

\& K. Horiuchi. 1988. Additional notes on the life history of Nemalion vermiculare Suringar (Nemaliales, Rhodophyta). Ibid., 36:231-236.

- \& M. Kurogi. 1981. The life history of Gigartina ochotensis (Ruprecht) Ruprecht (Rhodophyta) in culture. J. Fac. Sci., Hokkaido Univ., Ser. V, 12: 165-171.

\& M. Ohta. 1975. The life history of Rhodophysema georgit Batters (Rhodopyta, Cryptonemiales). J. Jap. Bot., 50: 1-10.

— \& 1981 . Taxonomy and life history of Rhodophysema odonthaliae sp. nov. (Rhodophyta). Jap. J. Phycol., 29: 15-21.

, J.A. West \& M. Kurogi. 1987. Life history of a Mastocarpus species (Rhodophyta) from central Japan. J. Fac. Sci., Hokkaido Univ., Ser. V, 14: 11-38.

$-\ldots$, Y. Ohno \& M. Kurogi. 1984. Comparative reproductive patterns in culture of different Gigartina subgenus Mastocarpus and Petrocelis populations from northern Japan. Bot. Mag., Tokyo, 97: 107-125.

Matsuyama, K. \& T. Masaki. 1975. Culture studies of Symphyocladia latiuscula (Rhodophyceae, Rhodomelaceae). Bull. Fac. Fish., Hokkaido Univ., 25: 265-272.

Mayhoub, H. 1973. Cycle du développement de Calosiphonia vermicularis (J. Agardh) Schmitz (Rhodophycée, Gigartinale). C.R. Acad. Sci. Paris, Sér. V, 277: 1137-1140.

- 1975 . Nouvelle observations sur le cycle de développement du Calosiphonia vermicularis (J. Ag.) Sch. (Rhodophycée, Gigartinale). Ibid., 280: 2441-2443.

- , P. Gayral \& M.R. Jacques. 1976. Action de la composition spectrale de la lumière sur la 
croissance et la reproduction de Calosiphonia vermicularis (J. Agardh) Schmitz (Rhodophycées, Gigartinales). Ibid., 283: 1041-1044.

McCandless, E.L., J.A. West \& M.D. Guiry. 1982. Carrageenan patterns in the Phyllophoraceae. Biochem. System. Biol., 10: 275-284.

McLachlan, J. \& T. Edelstein. 1977. Life history and culture of Gracilaria foliifera (Rhodophyta) from South Devon. J. Mar. Biol. Ass. U.K., 57: 577-586.

Migita, S. \& Y. Kawamura. 1980. Life histories of Dudresnaya minima and Schizymenia dubyi in culture. Jap. J. Phycol., 28: 62.

Mitman, I.K. \& H.K. Phinney. 1985. The development and reproductive morphology of Halosaccion americanum I.K. Lee (Rhodophyta, Palmariales). J. Phycol., 21: 578-584.

Moe, R.L. 1979. Minium parvum gen. et sp. nov, a crustose member of the Rhodymeniales (Rhodophyta). Phycologia, 18: 38-46.

Morohoshi, H. \& M. Masuda. 1980. The life history of Gloiosiphonia capillaris (Hudson) CarmichaeI (Rhodophyceae, Cryptonemiales). Jap. J. Phycol., 28: 81-91.

Müller, F. \& E. Petronijevic̀. 1979. Untersuchungen zum Generationswechsel von Nemalion multifidum (Weber et Mohr.) J. Ag. Nova Hedwigia, 31: 293-318.

Nakahara, H. \& M. Masuda. 1971. Type of life cycle and geographical distribution of marine green and brown algae in Japan. Mar. Sci. Mon. 3(III): 24-26.

Notoya, M. 1986. Hypoglossum nipponicum (Delesseriaceae, Rhodophyta) in culture. Jap. J. Phycol., $34: 24-26$.

Ohgai, M. \& T. Matsui. 1976. Germination of carpospores and development of their sporelings in Grateloupia turuturu Yamada in vitro. J. Shimonoseki Univ. Fish., 24: 343-348.

Ohta, M. \& M. Kurogi. 1979. On the life history of Rhodochorton purpureum (Lightf.) Rosenvinge from Hokkaido in culture. Jap. J. Phycol., 27: 161-167.

Osterhout, W.J.S. 1896. On the life history of Rhabdonia tenera. Ann. Not., 10: 403-427.

Oza, R.M. 1977. Culture studies on induction of tetraspores and their subsequent development in the red alga Falkenbergia mufolanosa (Harvey) Schmitz. Bot. Mar., 20: 29-32.

Polanshek, A.R. \& J.A. West. 1977. Culture and hybridization on Gigartina papillata (Rhodophyta). J. Phycol., 13: 141-149.

Prince, J.S. 1979. The life cycle of Crouania plenospora Taylor (Rhodophyta, Ceramiales) in culture. Phycologia, 18: 247-250.

Rao, G.S.P. 1967. On the cytology and life history of Leveillea jungermannioides (Mart. et Her.) Harv. (preliminary note). Bot. Mar., 10: 167-168.

Rueness, J. 1971. Polysiphonia hemisphaerica Aresch. in Scandinavia. Norw. J. Bot., 18: 65-74.

. 1973. Culture and field observations on growth and reproduction of Ceramium strictum Harv. from the Oslofjord, Norway. Ibid., 20: 61-65.

- 1978. A note on development and reproduction in Gigartina stellata (Rhodophyceae, Gigartinales) from Norway. Br. Phycol. J., 13: 87-90.

__ \& P.A. Asen. 1982. Field and culture observations on the life history of Bonnemaisonia asparagoides (Woodw.) G. Ag. (Rhodophyta) from Norway. Bot. Mar., 25: 577-587.

- \& M. Rueness. 1980. Culture and field observations on Callithamnion bipinnatum and C. byssoides (Rhodophyta, Ceramiales) from Norway. Sarsia, 65: 29-34.

- \& - 1985. Regular and irregular sequences in the life history of Callithamnion tetragonum (Rhodophyta, Ceramiales). Br. Phycol. J., 20: 329-333.

Saunders, G.W. \& C.J. Bird. 1989. Considerations of life history, morphology and taxonomy in Rhodophysema georgii (Rhodophyta, Palmariales). Br. Phycol. J., 24: 63-64.

Shelvin, D.F. \& A.R. Polanshek. 1978. Life history of Bonnemaisonia geniculata (Rhodophyta). A laboratory and field study. J. Phycol., 14: 282-289.

Shimizu, T. \& M. Masuda. 1983. The life history of Farlowia irregularis Yamada (Rhodophyta, Cryptonemiales). Jap. J. Phycol., 31: 202-207.

Stegenga, H. 1978. The life history of Rhodochorton purpureum and Rhodochorton floridulum (Rhodophyta, Nemaliales) in culture. Br. Phycol., J., 13: 279-289.

- \& W.J. Borsje. 1976. The morphology and life history of Acrochaetium (Rhodophyta, Nema- 
liales). Acta Bot. NeerI., 25: 15-29.

- \& 1977. The morphology and life history of Acrochaetium polyblastum (Rosenv.) Boerg. and Acrochaetium hollandicum (Kylin) Hamel (Rhodophyta, Nemaliales). Ibid., 26: 451-470.

- \& M. Vroman. 1976. The morphology and life history of Acrochaetium densum (Drew) Papenfuss (Rhodophyta, Nemaliales). Ibid., 25: 257-280.

Sundene, O. 1962. Reproduction and morphology in strains of Antithamnion boreale originating from Spitsbergen and Scandinavia. 'Skr. Norske Vidensk.-Akad. I. Mat.-Nat. Kl., N.S., 5: 1-19.

- 1964. The conspecificity of Antithamnion sarniense and A. spirographidis in view of culture experiments. Nytt Mag. Bot., 12: 35-42.

Suneson, S. 1950. The cytology of bispore formation in two species in Lithophyllum and the significance of bispores in the Corallinaceae. Bot. Notiser, 1950:429-450.

- 1982. The culture of bisporangial plants of Dermatolithon litorale (Suneson) Hamel et Lemoire (Rhodophyta, Corallinaceae). Br. Phycol. J., 17: 108-116.

Thirb, H.H. \& K. Benson-Evans. 1982. Cytological studies on Lemanea fluviatilis L. in the River USK. Ibid., 17: 401-409.

Tokida, J. \& Y. Yamamoto. 1965. Syntagmatic germination of tetraspores in Pachymeniopsis yendoi. Phycologia, 5: 15-20.

Umezaki, I. 1977. Life histories in the Florideophyceae and their evolution. Acta Phytotax. Geobot, 28: $1-18$.

van der Meer, J.P. 1976. A contribution towards elucidating the life history of Palmaria palmata (=Rhodymenia palmata). Can. J. Bot., 54: 2903-2906.

1981. The life history of Halosaccion ramentaceum. Ibid., 59: 433-436.

\& C.J. Bird. 1985. Palmaria mollis stat. nov.: a newly recognized species of Palmaria (Rhodophyceae) from the northeast Pacific. Ibid., 63: 398-403.

— \& L.C.-M. Chen. 1979. Evidence for sexual reproduction in the red algae Palmaria palmata and Halosaccion ramentaceum. Ibid., 57: 2452-2459.

— \& E.R. Todd. 1977. Genetics of Gracilaria sp. (Rhodophyceae, Gigartinales). IV. Mitotic recombination and its relationship to mixed-phases in the life history. Ibid., 55:2810-2817.

- \& -1980 . The life history of Palmaria palmata in culture. A new type for the Rhodophyta. Ibid., 58: 1250-1256.

von Stosch, H.A. 1969. Observations on Corallina, Jania and other red algae in culture. Proc. 6th Int. Seaweed Symp., Spain: 389-399.

\& C. Theil. 1979. A new mode of life history in the freshwater red algal Batrachospermum. Amer. J. Bot., 66: 105-107.

West, J.A. 1968. Morphology and reproduction of the red alga Acrochaetium pectinatum in culture. J. Phycol., 4: 89-99.

1969. The life history of Rhodochorton purpureum and $R$. tenue in culture. Ibid., 5: 12-21.

- 1970. The life history of Rhodochorton concrescens in culture. Br. Phycol. J., 5: 179-186.

. 1979. The life history of Rhodochorton membranaceum, an endozoic red alga. Bot. Mar., 22: $111-115$.

- \& H.R. Calumpong. 1988a. Mixed reproduction of Bostrychia (Ceramiales, Rhodophyta) in culture. I. B. tenella (Lamouroux) J. Agardh. Jpn. J. Phycol., 36: 292-310.

\& 1988b. Dawsoniocolax bostrychia (Choreocolaceae, Gigartinales), an alloparasitic red alga new to Australia. Phycologia, 27: 463-468.

- \& M.D. Guiry. 1982. A life history study of Gigartina johnstonii (Rhodophyta) from the Gulf of California. Bot. Mar, 25: 205-211.

- - , \& M. Masuda. 1983. Further investigations on the genetic affinities and life history patterns of the red alga Gigartina. In: G.K. Tseng, ed., Proc. Joint China-U.S. Phycological Symposium, Quingdao, pp. 137-166. Sci. Press, Beijing.

— \& M.H. Hommersand. 1981. Rhodophyta: Life history. In: C.S. Lobban \& M.J. Wynne, eds., The Biology of Seaweeds, pp. 133-193. Blackwell, Oxford.

\& R.E. Norris. 1966. Unusual phenomena in the life history of Florideae in culture. J. Phycol., 2: 54-57. 
, A.R. Polanshek \& M.D. Guiry. 1977. The life history in culture of Petrocelis cruenta J. Agardh (Rhodophyta) from Ireland. Br. Phycol. J., 12: 45-53.

J. Phycol., 14: 416-426.

Whittick, A. 1978. The life history and phenology of Callithamnion corymbosum (Rhodophyta: Ceramiaceae) in Newfoundland. Can. J. Bot., 56: 2497-2499.

- 1981. Culture and field studies on Callithamnion hookeri (Dillw.) S.F. Gray (Rhodophyta: Ceramiaceae) from Newfoundland. Br. Phycol. J., 16: 289-295.

\& J.A. West. 1979. The life history of a monoecious species of Callithamnion (Rhodophyta, Ceramiaceae) in culture. Phycologia, 18: 30-37.

Yabu, H. 1971. Nuclear division in tetrasporophytes of Rhodymenia palmata (L.) Grev. Proc. 7th Int. Seaweed Symp., Sapporo: 205-207.

1976. A report on the cytology of Rhodymenia palmata, Rh. pertusa and Halosaccion saccatum (Rhodophyta). Bull. Fac. Fish., Hokkaido Univ., 27: 51-62.

Yamamoto, H. \& J. Sasaki, 1987. Crossing experiments between populations of so-called Gracilaria verrucosa (Huds.) Papenfuss from two localities, Shinori and Kikonai in Hokkaido. Ibid., 38: 335-338.

Yarish, C., A.M. Breeman \& V. van den Hoek. 1984. Temperature, light, and photoperiod responses of some Northwest America and West European endemic rhodophytes in relation to their geographical distribution. Helgoländer Meeresunters., 38: 273-304.

Zupan, R.Z. \& J.A. West. 1988. Geographic variation in the life history of Mastocarpus papillatus (Rhodophyta). J. Phycol., 24: 223-229. 